Int. J. Dev. Biol. 58: 75-78 (2014)

doi: $10.1387 / \mathrm{ijdb} .140075 \mathrm{id}$

\title{
Decidua and implantation of the embryo from a historical perspective
}

\author{
IVAN DAMJANOV* \\ Department of Pathology and Laboratory Medicine, The University of Kansas School of Medicine, \\ Kansas City, Kansas, USA
}

\begin{abstract}
Implantation of the embryo is critical for the initiation of intrauterine development of early embryos. It depends on the proper soil formed by the decidualized pregnant uterus. In the present article I have reviewed the evolution of the modern concepts of decidualization and embryonic implantation, emphasizing how closely interrelated these two processes are. Special emphasis and recognition is given to the Boston pathologist Arthur T. Hertig, who studied for 15 years with another Bostonian, John Rock, a gynecologist, human implantation and early embryogenesis, thus providing the basis for future studies of human reproductive biology, infertility and contraception.
\end{abstract}

KEY WORDS: implantation, decidua, history

\section{Introduction}

The history and lore of human conception, intrauterine implantation and development of the embryo, placentation and the development of the fetal-placental unit are topics that have been extensively reviewed in many comprehensive articles including some of which were published even in this journal, The International Journal of Developmental Biology (Alexandre, 2001; Longo and Reynolds, 2010). Numerous monographs have been devoted to the same themes. The most memorable illustrations from these monographs have been reproduced by Longo and Reynolds (2010). Historical vignettes and overviews may be found in the well-known textbooks and monographs (Benirschke and Driscoll, 1967; Boyd and Hamilton, 1970; Mossman, 1987; Kraus, Damjanov and Kaufman, 1991). The Encyclopedia of Reproduction, compiled in four volumes by Knobil and Neill (1998) contains numerous references to historical events that preceded our modern concepts of reproductive biology in animals and humans.

Many of the great physicians and scientists of yore have studied placentation and the morphology and function of the placenta and the gravid uterus. The theories of placentation and related subjects up to 1900 have been comprehensively reviewed by De Witt (1959). The list of the luminaries who have studied this aspect of human reproduction is long and I will mention only the most resonant names of scientists and physicians who lived in the Middle ages and up to the early $20^{\text {th }}$ century: Leonardo da Vinci, Andreas Vesalius, Guilio Cesare Aranzi [Arantius], Girolamo Fabrizio [Fabricius ab Aquapendente], Nicholas Hoboken, Walter
Needham, Erasmus Darwin, John and William Hunter, Karl Friedrich Burdach, Ambrosius A.W. Hubrecht, and Charles Sedgwick Minot.

Several eponyms in the field of placentology have survived the scientists and physicians whose names they bear. From the perspective of a pathologist the most recognizable is Theodore Langhans who as professor of pathology in Basel described the cytotrophoblastic layer of the chorionic villi that was known for a long time by his name. J. Isfred Isidore Hofbauer, an American gynecologist described the macrophages in the chorionic villi and these cells are still best known under his name. Raissa Nitabuch is remembered for having described in her doctoral thesis the fibrin layer in the placenta that is still known by her name (Pijnenborg and Vercruysse, 2008). Mathias Marie Duval, eponymically known to pathologists for the so called Schiller-Duval bodies in yolk sac tumors of the testis and ovary described the endodermal sinuses of the rodent's placenta and actually even more importantly was one of the first to describe the invasion of maternal spiral arteries by trophoblastic cells (Longo and Reynolds, 2010).

For a student of history it is however regrettable that the contributions of many of our forebears will remain covered by the dust of history. Some of them may be rediscovered and given their due, such as Realdo Colombi, a sixteenth century Italian physician who gave the placenta its present day's name (Pizzi et al., 2012). The names of some others may resurface in another context. For example, Ambrosius A.W. Hubrecht, the embryologist who introduced the term trophoblast, is today better known by the famous Institute of Embryology in Utrecht, The Netherlands, which bears his name (Pijnenborg, 1998a; Pijnenborg and Vercruisse, 2013).

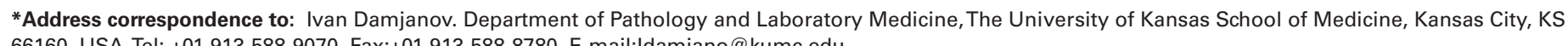
66160, USA. Tel: +01-913-588-9070. Fax:+01-913-588-8780. E-mail:Idamjano@kumc.edu

Final, author-corrected PDF published online: 8 July 2014.

ISSN: Online 1696-3547, Print 0214-6282 
The history of human and animal fertilization, intrauterine ontology and placentology is replete with stories about discoveries that were disputed, discoveries that were contested, and even discoveries that could never be reproduced. Still many published data were proven to be of lasting value and it is only fair to state, that despite many distractions and false beliefs the work of numerous scientists and physicians, especially during the last 100 years has significantly expanded our understanding of the early stages of human life in utero and the interface on the placental bed (Pijnenborg, 1998b). Many clinical advances are based on this research culminating in the development of routine techniques for in vitro fertilization. The ancient Latin saying: Historia est magistra vitae (History is the teacher of our lives) has never been brought to life in a better form. For one of the most riveting accounts of the $20^{\text {th }}$ century history of in vitro fertilization the reader should consult the

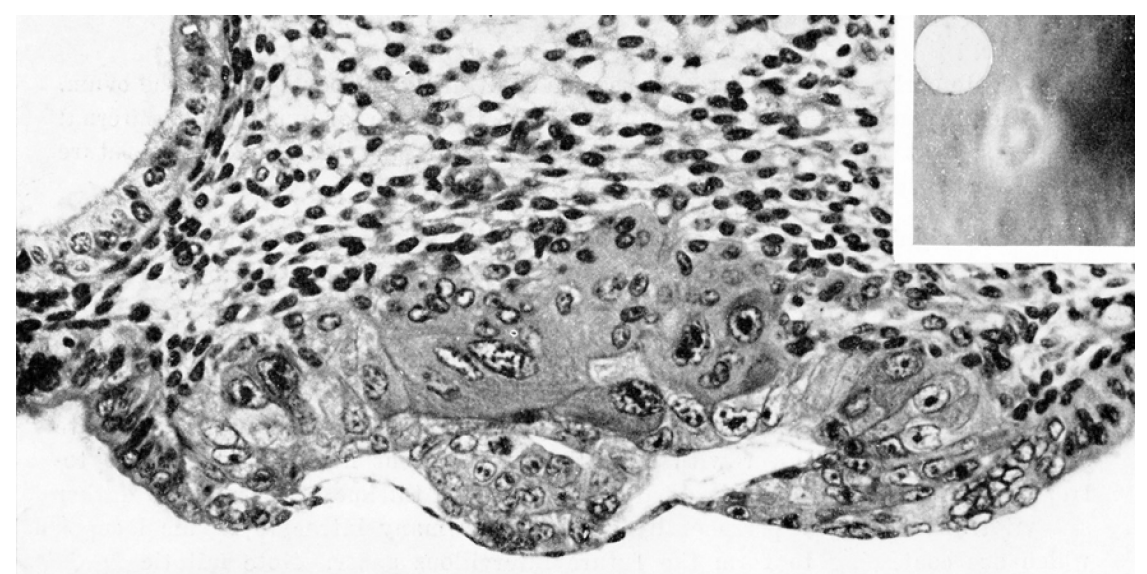

Fig. 1. A human embryo in early postimplantation stages of development (Carnegie specimen 8020). The implanted ovum is not more than 7.5 days of age. It consists of a germ disc and trophoblast located dorsally to it. (From Hertig et al., 1956, reproduced with the permission of the Publisher.

reminiscences of Biggers (2012). An interview with Allen Enders provides a personal view of the research in comparative placentology of our days (Thornburg and Hunt, 2010).

In this article I will review from a historical perspective two topics: the human decidua, a theme which has been of interest to me for some time and the description of embryonic implantation by a pathologist (Arthur $\mathrm{H}$. Hertig) whom I personally met in my younger days.

\section{Decidua}

The term membrana decidua was introduced into the medical scientific parlance by Andreas Vesalius, who included it in his drawing of a pregnant uterus (Damjanov, 1985). The term decidua implies that this uterine layer is to be shed at the time of delivery, in analogy to leafs falling from the branches of deciduous trees, or the deciduous teeth in children that do not last into adulthood. A more detailed description and depiction of this membrane can be found in the capital work of the 18th century British gynecologist William Hunter (1774). Longo and Reynolds (2010) have reproduced drawings from Hunter's book, which were transferred into copper-plate engravings by the Dutch artist Jan van Rymsdyk. It is also worth notice that Hunter distinguished the membrana decidua vera in the parietal layer from the capsular membrana decidua reflexa (De Witt, 1959). William Hunter also performed dye injection studies on pregnant uteri and thus demonstrated that the decidua is of maternal origin.

William's younger brother John contributed further to elucidating the nature of the decidua by noting that decidua develops in the uterus of women who had ectopic pregnancies. He also noticed decidua in both horns of bicornuate uteri, even though the pregnancy sac was only in one horn (De Witt, 1959). Even though he did not know any endocrinology and could not provide the explanation for the development of decidua, it is amazing that John Hunter actually anticipated our understanding of decidualization as a hormonally induced phenomenon (Gellersen and Brosens, 2003).

The transformation of endometrial stromal cells into decidual cells occurs in humans primarily in response to progesterone. The effects of progesterone appear early after ovulation (Gellersen et al.,
2007). Over a period of days the stromal cells undergo epithelioid transformation, and acquire intercellular junctions and secretory functions (Wewer et al., 1985; Sharkey and Maclon, 2013; Weimar et al., 2013). The glandular cells secrete substances that will be critical for sustaining the implanting embryo. The surface epithelial cells lining the uterine lumen activate genes regulating the expression of cell adhesion receptors and ligands. All these cellular and molecular aspects of decidualization have been discovered only recently and the research aimed at providing the missing details about the role of decidua in implantation are still a work in progress (Sharkey and Maclon, 2013; Weimar et al., 2013).

Decidualization is accompanied by a remarkable vascular

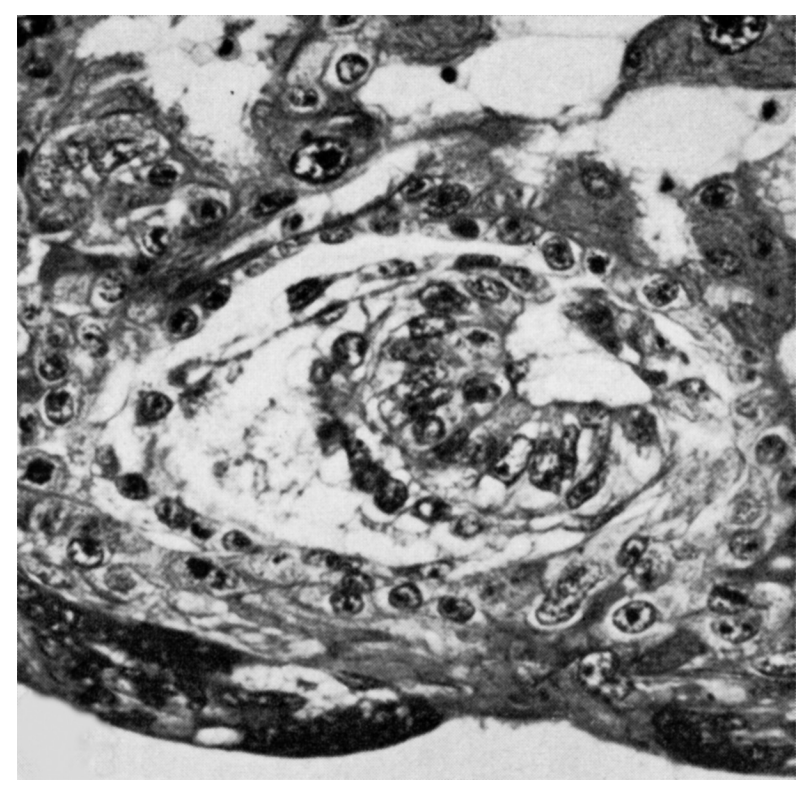

Fig. 2. A human embryo in early postimplantation stages of development (Carnegie specimen 8171). The implanted embryo forms a bilaminar disc with vacuolated ectoderm. It also shows early amniogenesis and early exocoelomic membrane delamination from the cytotrophoblast. From Hertig et al., 1956, reproduced with the permission of the Publisher. 
remodeling of uterine spiral arteries, which transform into lowresistance, high-capacitance vessels enabling the inflow of blood into the placenta (Cartwright et al., 2010). The blood flow from the maternal circulation into the placenta has intrigued the pioneers of placentology for many years as outlined in a historical review by Pijnenborg and Vercruysse (2008). Even though William Hunter realized that the placenta is the borderland between two separate circulatory systems, the maternal and fetal, it took many years until the exact mechanism of transfer of nutrients metabolites and gases was elucidated (Pijnenborg, 1998).

In addition to the endometrium derived stromal and glandular cells, which account for approximately $50 \%$ of all cells in the decidual membrane, this membrane contains also a significant number of lymphocytes, macrophages and leukocytes, accounting for $40 \%$ of all cells (Trundley and Moffett, 2004; Manaster and Mandelboim, 2010). In this population of cells there is a predominance of decidual natural killer cells (65-70\%), macrophages (15-20\%) and T lymphocytes (around 10\%). Like all other major developments in immunology, reproductiveimmunology has blossomed in the second part of the 20th century and the immune aspects of decidualization and placentation were essentially unknown to the early students of reproduction. The early reproductive immunologists considered the decidualized uterus as an immunologically privileged site (Kirby, 1968). Many immunologic aspects of pregnancy remain still unresolved, and their role in reproductive disorders is enigmatic (Lash and Bulmer, 2011). Current knowledge of the immunologic events occurring at the fetal-maternal interface has been comprehensively reviewed by Erlebacher (2013).

\section{Implantation}

Implantation of the human embryo into the uterus occurs at the blastocyst stage of development and comprises several sequential events (James et al., 2012 a,b). For obvious ethical reasons the study of human embryonic implantation cannot be experimentally monitored and most of the current research in this field is performed on models combining various in vitro approaches (Weimar et al., 2013). For actual morphologic studies of human implantation we are compelled to revisit some of the classical studies performed on pregnant uteri obtained from volunteers by a Boston gynecologist (John Rock) and a pathologist (Arthur T. Hertig). Their 15 year long search for implanting human ova and early embryos in the pregnant uteri was retold in a narrative reminiscence (Hertig, 1989). The authors have described their technique in yet another article which contains some original pictures of the dissection of the uteri and the instruments used for retrieval of the embryos (Hertig et al.,1956).

The story told by Hertig (1989) begins with his first encounter with Dr. Rock, whom he met as his professor of gynecology. Dr. Hertig graduated from Harvard Medical School and then joined as a fellow the Carnegie Institution of Washington's Department of Embryology (Baltimore, MD). There he joined master embryologists Geoge Linus Streeter, MD and Chester H. Heuser, PhD who taught him various techniques for studying embryos both human and nonhuman primate. After this apprenticeship and a pathology residency Dr. Hertig joined the staff of the Free Hospital for Women, Brookline, MA and began working with Dr. Rock.

Potential ovum donors, selected from women who were scheduled to have hysterectomies for medical reasons were selected by

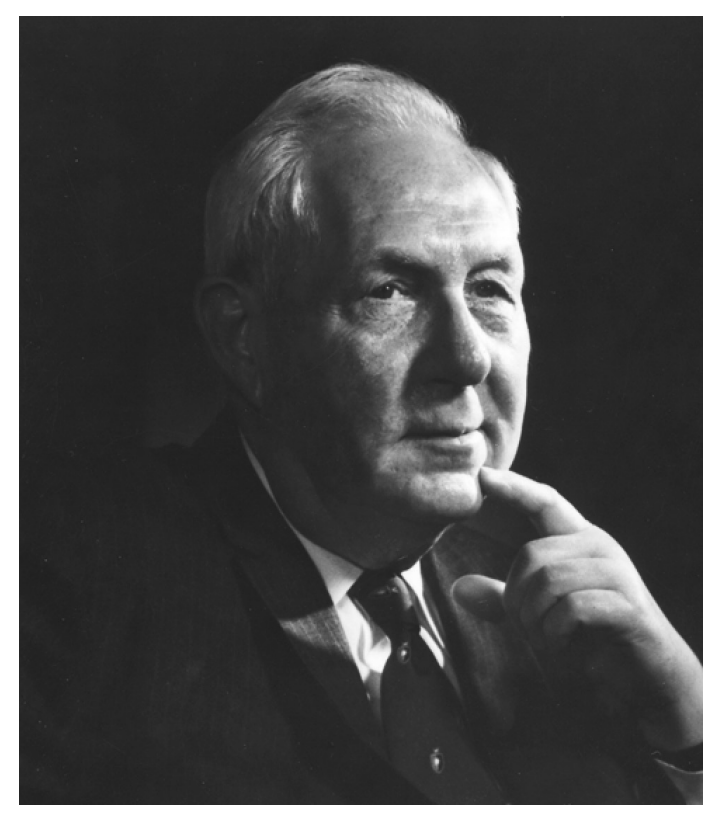

Fig. 3. Arthur T. Hertig (1904-1990), first class pathologist/embryologist, and scientist par excellence.

the staff and were referred to Dr. Rock. In order to be included in the study they had to meet following criteria: they had to be married and living with their husband, had to be intelligent, and had to have had at least three children. They also had to be willing to keep a record of their menstrual cycles and engaged in coitus with their husbands without contraception. These timed pregnancies were then interrupted by the previously planned and consented hysterectomy. The uterus tubes and ovaries removed surgically by Dr. Rock were handed over to Dr. Hertig, who dissected the specimen looking for an implantation site in the uterus containing the implanted ova. Over the 15 years Dr Hertig dissected 210 specimens and found 21 normal ova/embryos and 13 abnormal ones (Hertig, 1989). The data on all these 34 ova/embryos were reported in the Carnegie monographs entitled Contributions to Embryologyand the summary data with selected photographs were then published in the American Journal of Anatomy (Hertig et al., 1956). Some of these historical and definitely unique pictures are reproduced in this article (Figs. 1-2).

I met Dr. A.T.Hertig in a few months before his death in 1990. That year, Fred Kraus and I had organized a long course on $\mathrm{Pa}$ thology of Reproductive Failure for the United States-Canadian Academy of Pathology (Kraus et al., 1991). The course was held in Boston and thus we decided to invite Dr. Hertig to address the pathologists attending the course. He accepted our invitation, even though he was 86 years old, and I still remember how he regaled us all with his stories during the gala dinner. He also gave us his photographic portrait (Fig. 3). A few months later he died. The obituary cited his work on early-fertilized human ova, his 37 years of service as pathologist, and his contributions to research effort of the Primate Research Center where he worked after retirement from Harvard. I never met Dr. Rock, one of the pioneers of human reproductive medicine. Following his study with Dr. Hertig, Dr. Rock discontinued working on embryos, but then joined Dr. Gregory Pincus to develop oral contraceptives. Their work ultimately led to widespread use of the "pill" for hormonal contraception. It is one of 
the prime examples of how the work on basic aspects of biology can result in major advances of human medicine.

\section{Aknowledgement}

Figures from the article HERTIG AT, ROCK J, ADAMS EC (1956). A description of 34 human ova within the first 17 days of development. Am J Anat 98: 435-494, reproduced with permission of the Publisher Copyright (1956) Wiley.

\section{References}

ALEXANDRE H (2001). A history of mammalian embryological research. Int J Dev Biol 45: 457-467.

BENIRSCHKE K, DRISCOLL SG (1967). The pathology of the human placenta. Springer, Berlin.

BIGGERS JD (2012). IVF and embryo transfer: historical origin and development. Reprod. Biomed. Online 25:118-27.

BOYD JD, HAMILTON WJ (1970). The human placenta. Heffer and Sons, Cambridge.

CARTWRIGHT JE, FRASER R, LESLIE K, WALLACE AE, JAMES JL (2010). Remodeling at he maternal-fetal interface: relevance to human pregnancy disroders. Reproduction 140: 803-813.

CROSS JC, WERB Z, FISHER SJ (1994). Implantation and the placenta: key pieces of the development puzzle. Science 266: 1508-1517.

DE WITT F(1959). An historical study on theories of the placenta to 1900. J Hist Med 14: 360-374.

ERLEBACHER A (2013). Immunology of the maternal-fetal interface. Ann Rev Immunol 31: 387-411.

GELLERSEN B, BROSENS J (2003). Cyclic AMP and progesterone receptor crosstalk in human endometrium: a decidualizing affair. J Endocrinol 178: 357-372.

GELLERSEN B, BROSENS IA, BROSENS JJ (2007). Decidualization of the human endometrium: mechanisms, functions, and clinical perspectives. Sem Reprod Med 25: 445-453.

HERTIG AT (1962) The placenta: some new knowledge about an old organ. Obstet Gynecol 20: 859-866.

HERTIGAT (1989). Afifteen-year search for first-stage human ova. JAMA261:434-435.

HERTIG AT, ROCK J (1973). Searching for early fertilized human ova. Gynec Invest 4: 121-139.

HERTIG AT, ROCK J, ADAMS EC (1956). A description of 34 human ova within the first 17 days of development. Am J Anat 98: 435-494.

HUNTER W (1774). Anatomia uteri humani gravidi tabulis illustrata. John Baskerville, Birmingham (1980, Facsimile edition, Gryphon Editions, Birmingham, Alabama)
JAMES JL, CARTER AM, CHAMLEY LW (2012a). Human placentation form nidation to 5 weeks of gestation. Part I: What do we know about formative placental development following implantation? Placenta 33: 327-334.

JAMES JL, CARTER AM, CHAMLEY LW (2012b). Human placentation form nidation to 5 weeks of gestation. Part II: Tools to model the crucial first days. Placenta 33: $335-342$

KNOBILL E, NEILL JD (Eds) (1998). Encyclopedia of reproduction. Academic Press, San Diego, CA.

KRAUS FT,DAMJANOV I, KAUFMAN N (1991). Pathology of reproductive failure. Williams \& Wilkins, Baltimore, MD.

KIRBYDRS (1968). Immunological aspects of pregnancy. Adv Reprod Physio/3:33-79.

LASH GE, BULMER JN (2011). Do uterine natural killer (uNK) cells contribute to female reproductive disorders? J Reprod Immunol 88: 156-164.

MANASTER I, MANDELBOIM O (2010). The unique properties of uterine NK cells. Am J Reprod Immunol 63: 434-444.

LONGO LD, REYNOLDSLP(2010). Some historical aspects of understanding placental development, structure and function. Int J Dev Biol 54: 237-255.

MOSSMAN HW (1987). Vertebrate fetal membranes: comparative ontogeny and morphology; evolution; phylogenetic significance; basic functions; research opportunities. Rutgers University Press, New Brunswick, NJ.

PIJNENBORG R (1998a). The origin and future of placental bed research. Eur J Obstet Gynecol 81: 185-190.

PIJNENBORG R (1998b). The human decidua as a passage-way for trophoblast invasion. A review. Trophoblast Res 11: 229-241.

PIJNENEBORG R, VERCRUYSSE L (2008). Shifting concepts of the fetal-maternal interface: a historical perpsective. Placenta 22: S20-S25.

PIJNENEBORG R, VERCRUYSSE L (2013). A.A.W. Hubrecht and the naming of the trophoblast. Placenta 34: 341-319.

PIZZI M, FASSAN M, CIMINO M, ZANARDO V, CHIARELLI S (2012). Realdo Colombo's De Re Anatomica: The renaissance origin of the term "placenta" and its historical background. Placenta 33: 655-657.

SHARKEY AM, MACKLON NS (2013). The science of implantation emerges blinking into the light. Reprod Biomed Online 27: 451-460.

THORNBURG KK, HUNT JS (2010). Contemporary comparative placenta researchan interview with Allen Enders. Int J Dev Biol 54: 231-236.

TRUNDELY A, MOFFETT A (2004). Human uterine leukocytes and pregnancy. Tissue Antigens 63:1-12.

WEIMAR CHE, POST UITERWEER ED, TEKLENBURG G, HEIJNEN CJ, MACKLON NS (2013). In-vitro model systems for the study of human embryo-endometrium interactions. Reprod Biomed Online 27: 461-476.

WEWER UM, FABER M, LIOTTA LA, ALBRECHTSEN R (1985). Immunochemical and ultrastructural assessment of the nature of pericellular basement membrane of human decidual cells. Lab Invest 53: 624-633. 


\section{Further Related Reading, published previously in the Int. J. Dev. Biol.}

Testicular germ cell tumors and related research from a historical point of view Ivan Damjanov and Nicolai Wewer-Albrechtsen

Int. J. Dev. Biol. (2013) 57: 197-200

http://dx.doi.org/10.1387/ijdb.130143id

Above the borderland between normal and neoplastic development Juan Aréchaga and Ivan Damjanov

Int. J. Dev. Biol. (2012) 56: 939-948

http://dx.doi.org/10.1387/ijdb.120255ja

The quest for hematopoietic stem cells in the embryo. An interview with Françoise Dieterlen-Lièvre

Thierry Jaffredo and Charles Durand

Int. J. Dev. Biol. (2010) 54: 1075-1078

http://dx.doi.org/10.1387/ijdb.103153tj

On the origin of amniotic stem cells: of mice and men

Mariya P. Dobreva, Paulo N.G. Pereira, Jan Deprest and An Zwijsen

Int. J. Dev. Biol. (2010) 54: 761-777

http://dx.doi.org/10.1387/ijdb.092935md

Placentation in mammals once grouped as insectivores

Anthony M. Carter and Allen C. Enders

Int. J. Dev. Biol. (2010) 54: 483-493

http://dx.doi.org/10.1387/ijdb.082830ac

The hidden maternal-fetal interface: events involving the lymphoid organs in maternalfetal tolerance

Elizabeth S. Taglauer, Kristina M. Adams Waldorf and Margaret G. Petroff

Int. J. Dev. Biol. (2010) 54: 421-430

http://dx.doi.org/10.1387/ijdb.082800et

Some historical aspects of understanding placental development, structure and function Lawrence D. Longo and Lawrence P. Reynolds

Int. J. Dev. Biol. (2010) 54: 237-255

http://dx.doi.org/10.1387/ijdb.082774II

5 yr ISI Impact Factor $(2011)=2.959$
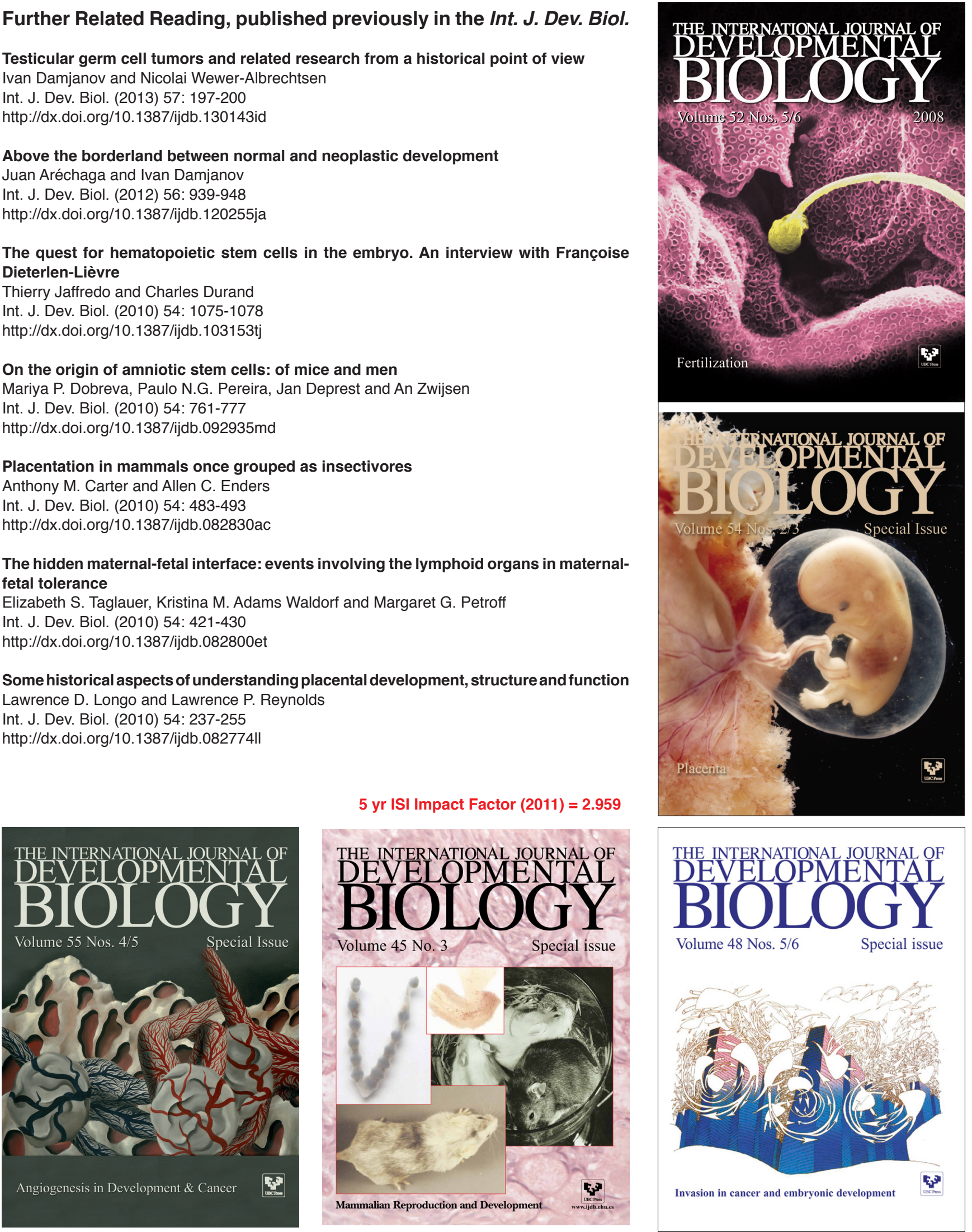

Volume 48 Nos. 5/6

Special issue

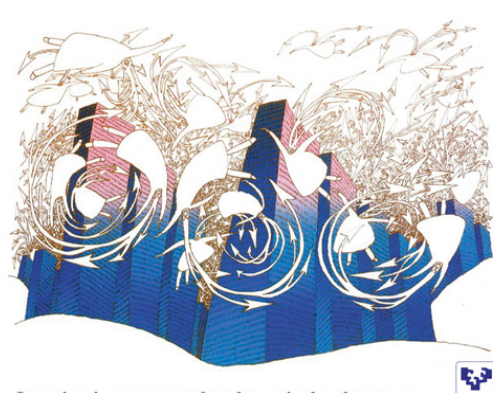

Invasion in cancer and embryonic development 